\title{
Incidental Asymptomatic Accessory Mitral Valve: a Differential Diagnosis for Intracardiac Mass
}

\section{Achado Acidental de Válvula Mitral Acessória: um Diagnóstico Diferencial de Massa Intracardíaca}

Esra DONMEZ1 ${ }^{1}$, Taner SEKER ${ }^{1}$, Yahya Kemal ICEN ${ }^{1}$, Zafer ELBASAN ${ }^{1}$, Mustafa GUR ${ }^{1}$, Murat CAYLI ${ }^{1}$ Acta Med Port 2014 Nov-Dec;27(6):779-782

\section{ABSTRACT}

Accessory mitral valve is a rare entity which is commonly detected in children. It might present as a cause for left ventricular outflow obstruction, aortic regurgitation or a source for thromboembolic event. Diagnosis is based on echocardiographic findings, transesophageally when possible. Usually treatment is not required however treatment decisions are based on associated abnormalities

1. Department of Cardiology. Adana Numune Research and Training Hospital. İstanbul. Türkiye.

Recebido: 20 de Novembro de 2013 - Aceite: 19 de Setembro de 2014 | Copyright @ Ordem dos Médicos 2014 
and symptoms. Our aim is to report a case which was referred to our clinic as a suspected intracardiac mass.

Keywords: Heart Defects, Congenital; Mitral Valve/abnormalities.

\section{RESUMO}

A válvula mitral acessória constitui uma entidade rara, sendo habitualmente detectada em crianças. Pode surgir associada a um quadro de obstrução do tracto de saída do ventrículo esquerdo, de regurgitação aórtica ou como ponto de origem de um evento tromboembólico. O diagnóstico baseia-se nos achados do ecocardiograma, sempre que possível por via trans-esofágica. Não requer habitualmente tratamento; a decisão terapêutica deve contudo basear-se nas alterações e sintomas que lhe estão associados. É descrito um caso clínico que nos foi referenciado no contexto de uma massa intracardíaca suspeita.

Palavras-chave: Deficiências Cardíacas Congénitas; Válvula Mitral/anómalias congénitas.

\section{INTRODUCTION}

The accessory mitral valve (AMV) is a rare congenital cardiac anomaly and its incidence is one per 26000 echocardiograms. ${ }^{1}$ It was first described in 1842 by Cheevers while the first surgical intervention is made in 1963 by McLean. ${ }^{2}$ The etiology of the disease is not completely understood but it is thought to arise from an endocardial cushion defect. Occasionally AMV is accompanied by congenital abnormalities of the heart (ventricular septal defect, patent ductus arteriosus, Ebstein anomaly) and transposition of great vessels. The degree of left ventricular outflow obstruction is associated with the symptoms such as chest pain, exercise intolerance or syncope. When symptomatic, it is generally diagnosed in childhood. We are presenting an adult case who presented with systolic murmur and a suspected intracardiac mass on transthoracic echocardiography.

\section{CASE REPORT}

A 55 year-old male without any history of cardiac diseases was assessed by an anesthesiologist prior to a pilonidal sinus operation. Upon his physical examination systolic murmur was detected. Afterwards he was counselled to the cardiologist in the same state hospital. A 2/6 systolic murmur was confirmed while a suspected intracardiac mass related with the aortic valve was detected on transthoracic echocardiography (Fig.s 1,2). He was referred to our clinic for further investigation.

On physical examination 2/6 mid-systolic murmur on left sternal border was detected. Electrocardiographic findings and laboratory tests were within normal range. On transthoracic echocardiography (TTE) ejection fraction was 0.60 while the cardiac chambers were of normal size. No left ventricular hypertrophy was observed. A mass like structure which was attached to the ventricular part of the anterior mitral laeflet was discovered. No aortic regurgitation and left ventricular outflow obstruction (LVOT) obstruction were detected (resting and exercise peak pressure gradient across LVOT was $8 \mathrm{mmHg}$ ). During transeosaphageal echocardiography a mobile, echogenic, chorda tendinea like structure which was attached to the ventricular side of the anterior mitral valve was observed (Fig. 3). It was thought to be an AMV. No other congenital heart disease and aortic regurgitation was found. Annual echocardiographic followup was planned since the patient was symptom free.

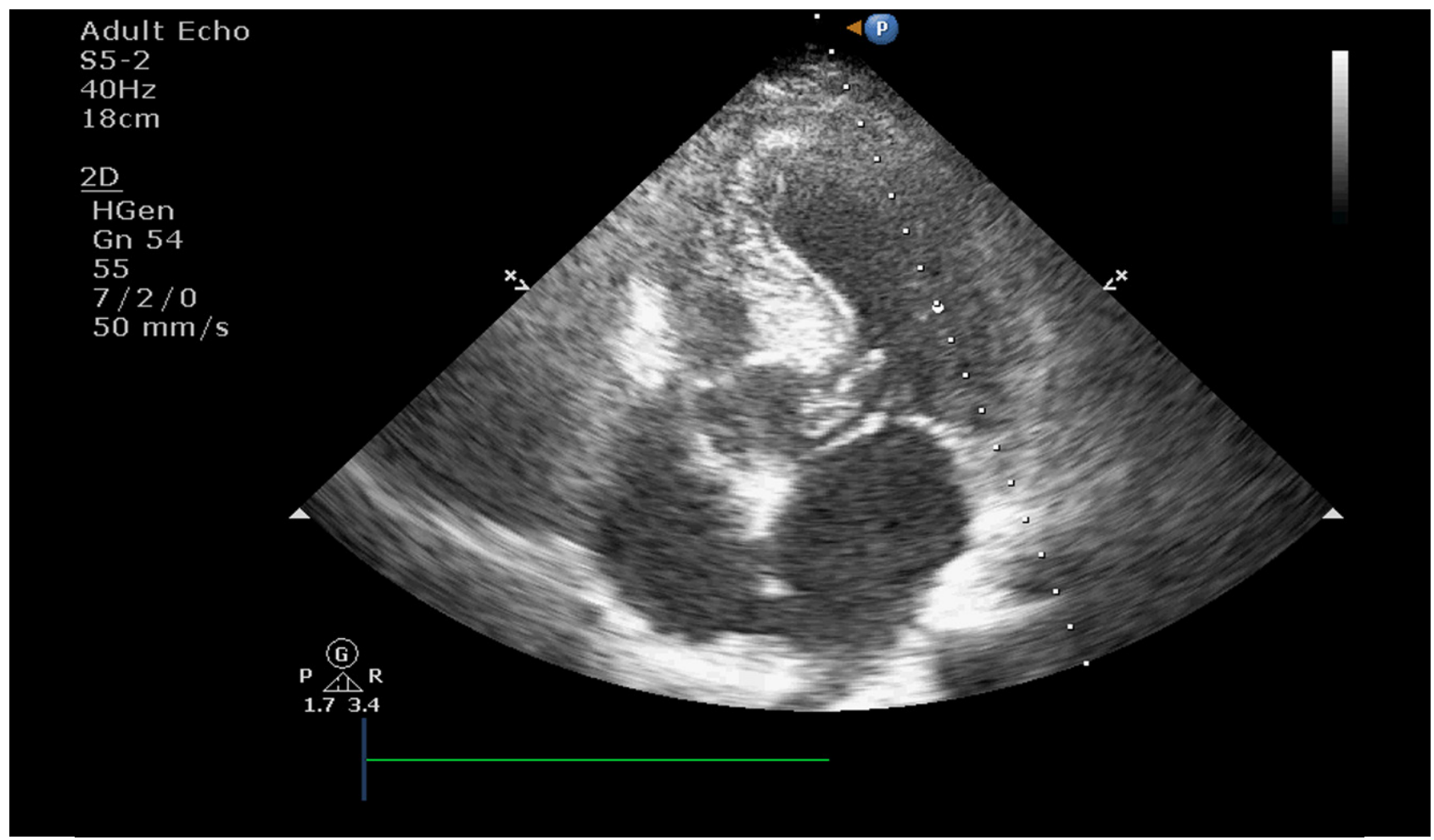

Figure 1 - Transthoracic echocardiographic image of accessory mitral valve 


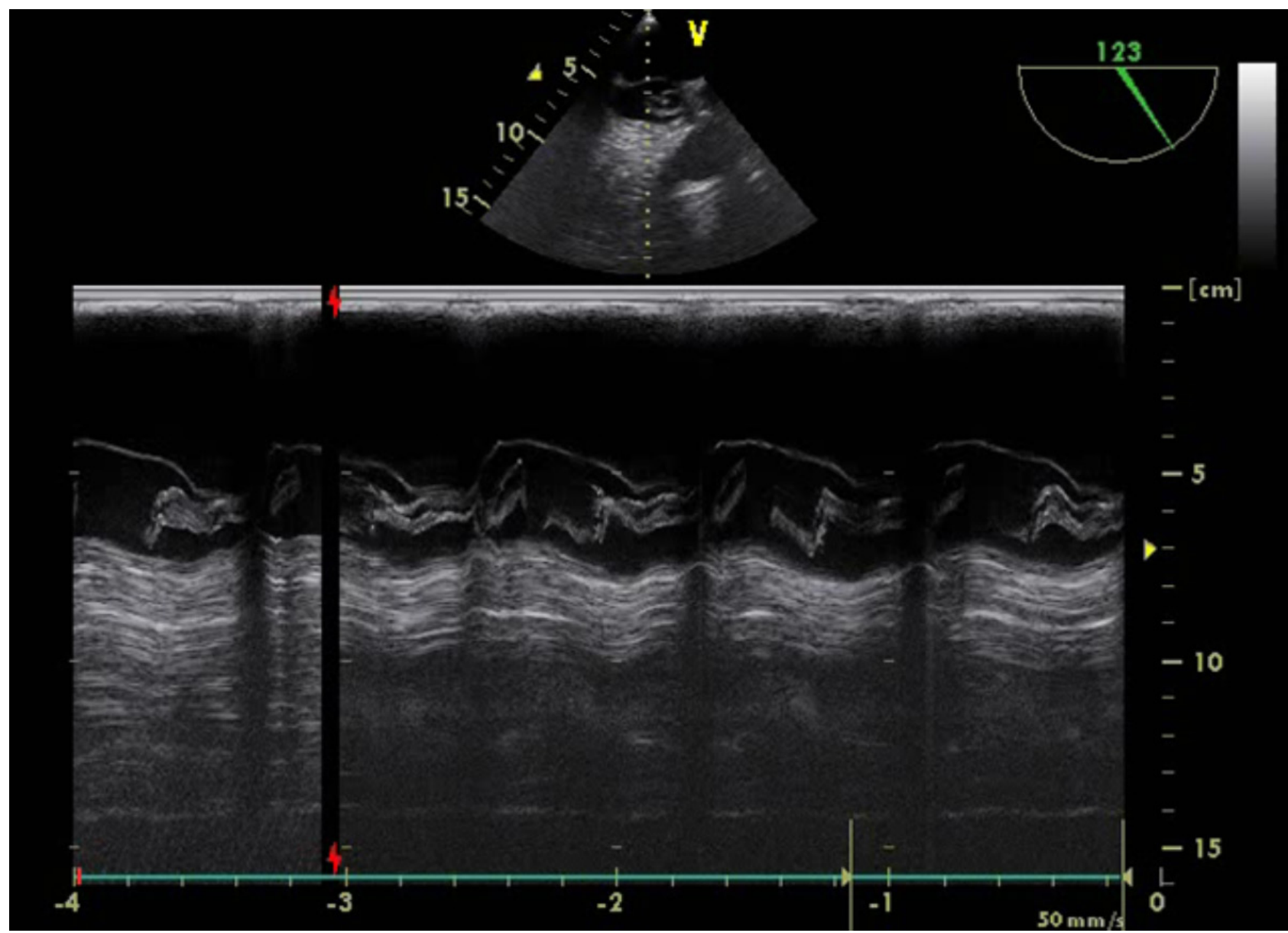

Figure 2 - Transthoracic echocardiographic image of accessory mitral valve (M mode)

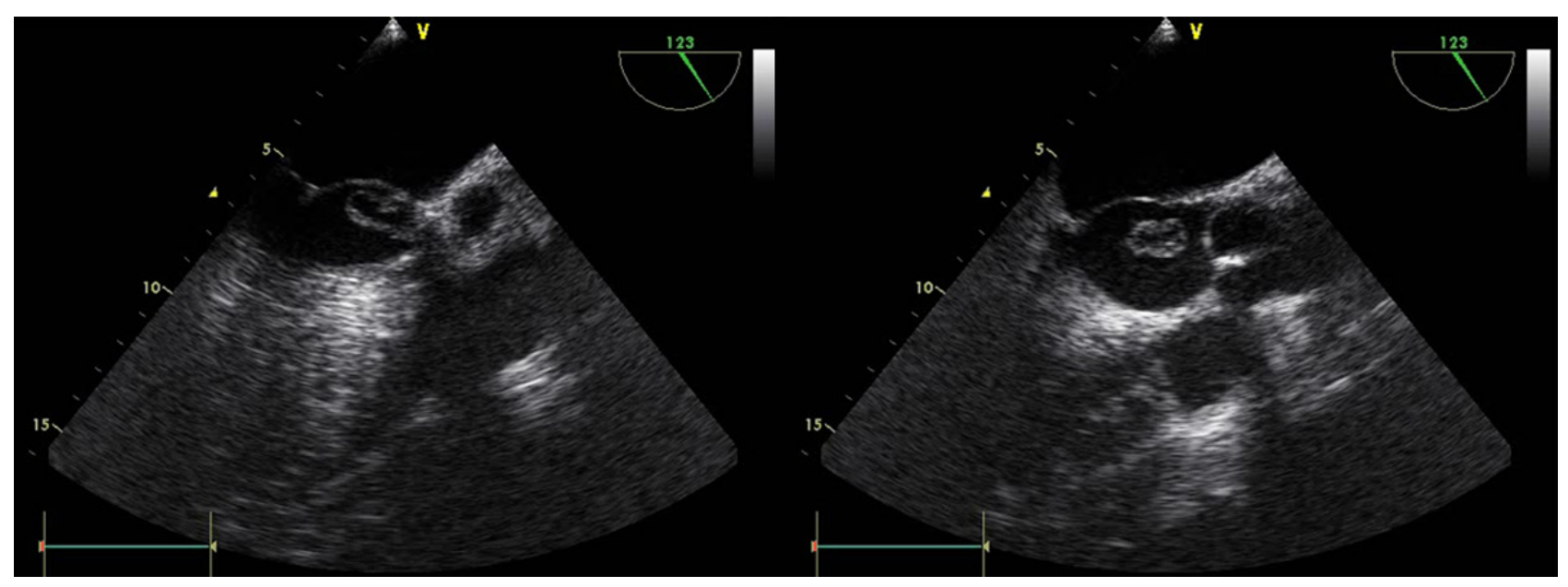

Figure 3 - Transeasophageal image of accessory mitral valve

\section{DISCUSSION}

Accessory mitral valve tissue is a rare congenital cardiac malformation. ${ }^{3}$ The widespread use of transthoracic echocardiography in the last decades brought up easier diagnosis upon first description by Cheevers in 1842 . The patients are usually asymptomatic however they are referred to echocardiography because of systolic murmur. The mechanisms of LVOT obstruction are thought to be due to mass effect of the accessory valve tissue or fibrous tissue deposition resulting a turbulent flow. Symptomatic cases are usually diagnosed in the early childhood. Symptoms include exercise intolerance, chest pain on exertion, syncope or transient ischemic attack. ${ }^{1,4,5}$ Obstruction and other coexisting cardiac anomalies are observed in patients with symptoms regardless from age. ${ }^{3,6,7}$

Transthoracic echocardiography is the key step in diagnosis. The mass like structure is usually observed in the subaortic area. The Doppler echocardiography should be used to demonstrate the gradient between the left ventricule and the aorta. ${ }^{1}$ Other LVOT masses like myxoma, 
papillary fibroleastoma, thrombus or vegetations should be differentiated from AMV by TTE and transeaosophageal echocardiography. ${ }^{8}$

Embryologically, AMV is the result of incomplete seperation of the mitral valve tissue from the endocardial cushion. 19,10 Two types of accessory valve tissue were defined by Faggian et al in 1983.7 The mobile type is a parachute-like leaflet floating in the ventricular outflow tract. LVOT obstruction may be caused by mobile type. The fixed type is attached to the interventriular septum firmly and this type may sometimes decrease the size of interventricular defect.

Surgical resection of the AMV is needed when it is symptomatic and related to LVOT obstruction. Surgery usually resolves the symptoms. There is insufficient data regarding the follow-up of asymptomatic cases. The surgical approach for obstructed cases is not well established in the literature.

With regard to this case, AMV should be kept in mind in

\section{REFERENCES}

1. Rovner A, Thanigaraj S, Perez JE. Accessory mitral valve in an adult population: the role of echocardiography in diagnosis and management. J Am Soc Echocardiogra. 2005;18:494-8.

2. McLean LD, Kane DJ. Subaortic stenosis due to accessory mitral valve. J Thorac Cardiovasc Surg. 1963;45:383-8.

3. Yasui H, Kado H, Tokunaga S, Kanegae Y, Fukae K, Masuda M, et al. Trans-ventricular septal defect approach for resection of accessory mitral valve tissue. Ann Thorac Surg. 1993;55:950-3.

4. Prifti E, Frati G, Bonacchi M, Vanini V, Chauvaud S. Accessory mitral valve tissue causing left ventricular outflow tract obstruction: case reports and literature review. J Heart Valve Dis. 2001;10:774-8.

5. Yetkin E, Turhan H, Atak R, Senen K, Cehreli S. Accessory mitral valve tissue manifesting cerebrovascular thromboembolic event in a 34-yearold woman. Int J Cardiol. 2003;89:309-11.

6. Gomes AS, Nath PH, Singh A, Lucas RV Jr, Amplatz K, Nicoloff DM, et the differential diagnosis for intracardiac masses. Careful transechocardiography is needed in order to detect such entity. Further imaging modalities are seldomly needed. No intervention or medication is necessary if the patient is symptom free. Although some authors recommend antibiotic prophylaxis in AMV, it is not indicated in European Society of Cardiology (ESC) Valvular Heart Disease Guidelines 2012. Current ESC guidelines do not recommend prophylaxis for thromboembolic events in AMV specifically. However there are case reports against this recommendation. Authors suggest individual decision for antiaggregant/antiplatellet prophylaxis.

\section{CONFLICTS OF INTEREST}

The authors declared that they have no conflicts of interest.

\section{FUNDING SOURCES}

None stated.

al. Accessory flaplike tissue causing ventricular outflow obstruction. J Thorac Cardiovasc Surg. 1980;80:211-6.

7. Faggian G, Frescura C, Thiene G, Bortolotti U, Mazzucco A, Anderson $\mathrm{RH}$. Accessory tricuspid valve tissue causing obstruction of the ventricular septal defect in tetralogy of Fallot. Brit Heart J. 1983;49:3247.

8. Panduranga $\mathrm{P}, \mathrm{Al}-\mathrm{Mukhaini} \mathrm{M}$. Isolated non-obstructive accessory mitra valve tissue in an adult mimicking ruptured chordae. Indian Heart $\mathrm{J}$. 2013;65:334-6.

9. Rozo JC, Medina D, Guerrero C, Calderon AM, Mesa A. Accessory mitral valve without left ventricular outflow tract obstruction in an adult Texas Heart Institute journal / from the Texas Heart Institute of St Luke's Episcopal Hospital, Texas Children's Hospital. 2008;35:324-6.

10. Uslu N, Gorgulu S, Yildirim A, Eren M. Accessory mitral valve tissue: report of two asymptomatic cases. Cardiology. 2006;105:155-7.

\section{Third Cranial Nerve Palsy in Sphenoid Sinusitis}

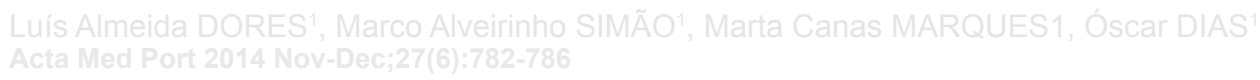




\section{Incidental Asymptomatic Accessory Mitral Valve: a Differential Diagnosis for Intracardiac Mass}

Acta Med Port 2014:27:779-782

Publicado pela Acta Médica Portuguesa, a Revista Científica da Ordem dos Médicos

Av. Almirante Gago Coutinho, 151

1749-084 Lisboa, Portugal.

Tel: +351218428215

E-mail: submissao@actamedicaportuguesa.com

www.actamedicaportuguesa.com

ISSN:0870-399X | e-ISSN: 1646-0758

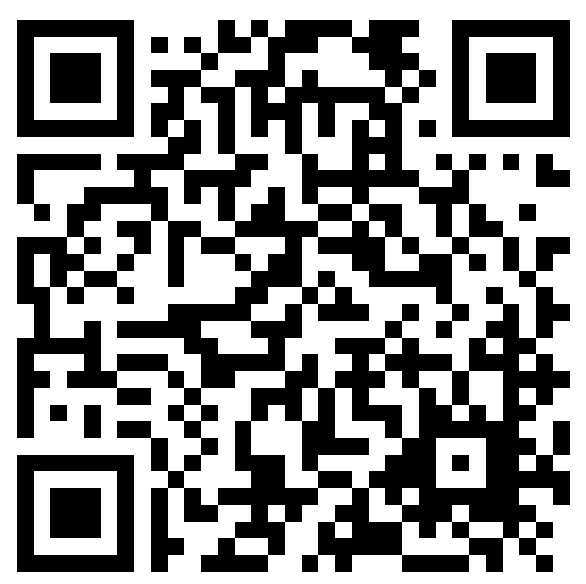

